\title{
UJI SELEKTIFITAS DAN SENSITIFITAS PEREAKSI UNTUK DETEKSI FORMALIN PADA BAHAN PANGAN
}

\section{SELECTIVITY AND SENSITIVITY REACTANTS TEST FOR FORMALIN DETECTION ON FOOD MATERIALS}

\author{
Denia Pratiwi, Isna Wardaniati, Asiska Permata Dewi \\ DIII Anafarma, Faculty of Medicine and Health Science, Abdurrab University, \\ Jl. Riau Ujung No 73, Pekanbaru-Riau, Indonesia \\ Email: denia.pratiwi@univrab.ac.id (Denia Pratiwi)
}

\begin{abstract}
ABSTRAK
Bahan pangan rentan untuk ditambahkan zat kimia berbahaya seperti formalin, apalagi pada bahan pangan yang kemungkinan banyak mengandung kadar air sehingga mudah busuk dan tidak tahan lama terhadap penyimpanan. Pemeriksaan formalin dalam bahan pangan dapat dilakukan dengan cara analisis kualitatif yang tidak memerlukan waktu lama dan lebih praktis tetapi jenis pereaksi yang dapat digunakan sangat banyak. Sehingga dibutuhkan pereaksi yang lebih selektif dan sensitif terhadap bahan pangan. Tujuan penelitian ini adalah untuk mengetahui selektifitas dan sensitifitas pereaksi pada bahan pangan. Penelitian ini dilakukan secara analisis deskriptif kualitatif dengan menggunakan pereaksi formalin (Schiff, Scryver, $\mathrm{KMnO}_{4}$, Fehling, dan Nash) terhadap sampel bahan pangan yaitu daging ayam, tahu, ikan asin, dan mie basah yang telah diberi formalin dengan variasi konsentrasi 0,$01 ; 0,1 ; 1,0 ; 10 ; 100$; dan 1000 ppm. Dari hasil penelitian analisis kualitatif terhadap formalin menunjukan pereaksi yang selektif untuk identifikasi formalin pada keempat bahan pangan adalah pereaksi Schiff, $\mathrm{KMnO}_{4}$, Scryver, Nash. Pereaksi yang sensitif terhadap formalin pada keempat bahan pangan hingga 0,01 ppm adalah Schiff dan $\mathrm{KMnO}_{4}$. Sedangkan pereaksi Scryver dan Nash hanya mampu mendeteksi formalin hingga konsentrasi 100 ppm.
\end{abstract}

Kata kunci: bahan pangan, formalin, selektivitas dan sensitifitas.

\section{ABSTRACT}

Foodstuffs containing high water content are easily spoilage by microorganisms and hence have a relatively short shelf life. To prolong their shelf life, a hazardous preservative, formalin, is sometimes irresponsibly added. A qualitative analysis of formalin is more practical and time efficient, as well as capable of evaluating the sensitivity and selectivity of the reactants to the food matrix. This is a qualitative descriptive analysis to evaluate the sensitivity and selectivity of formalin reagents (Schiff, Scryver, KMnO4, Fehling, and Nash reagents) to detect formalin added to food samples (chicken, tofu, salted fish, and wet noodles) in various concentrations of 0.01, 0.1, 1.0, 
10, 100, and $1000 \mathrm{ppm}$. The result showed that Schiff, $\mathrm{KMnO}_{4}$, Scryver, and Nash's reagents were selective reagents for identification of formalin in all evaluated food matrixes. The reagents that were sensitive to analyze formalin up to a concentration of $0.01 \mathrm{ppm}$ are Schiff and $\mathrm{KMnO}_{4}$. Scryver and Nash's reagents were only able to detect formalin at a concentration of $100 \mathrm{ppm}$.

Key words: foodstuffs, formalin, selectivity and sensitivity. 


\section{Pendahuluan}

Bahan Tambahan Pangan (BTP), seperti bahan pengawet, menjadi semakin marak digunakan seiring dengan kemajuan teknologi produksi bahan pangan sintesis. Bahan kimia yang sering digunakan salah satunya adalah formalin atau formaldehida yang merupakan bahan zat tambahan makanan yang dilarang (Jamlean, 2016). Formalin merupakan salah satu bahan kimia yang dilarang sebagai bahan pengawet makanan atau minuman karena residu formalin mengganggu kesehatan bagi yang memakannya (Drastini \& Widiasih, 2009).

Formalin biasanya mengandung metanol $10-15 \%$, yang berfungsi sebagai stabilisator untuk mencegah polimerisasi formaldehida menjadi paraformaldehida yang bersifat sangat beracun (Syafitri et al., 2012). Menurut penelitian sebelumnya, didapatkan bahwa 2 dari 10 sampel ikan asin yang diteliti di Kecamatan Tampan, Pekanbaru, positif mengandung formalin (Antoni, 2010). Pada penelitian Khaira didapatkan bahwa semua sampel tahu, yaitu 5 buah, positif menunjukkan adanya formalin (Khaira, 2016). Sementara itu Kusumawati dan Trisharyanti menemukan adanya formalin pada sampel mie basah di Pasar Surakarta (Kusumawati dan Trisharyanti, 2004).

Bahan pangan rentan untuk ditambahkan zat kimia berbahaya seperti formalin, apalagi pada bahan pangan yang kemungkinan banyak mengandung kadar air sehingga mudah busuk, tidak tahan lama terhadap penyimpanan. Pemeriksaan formalin dalam bahan pangan dapat dilakukan dengan cara analisis kualitatif yang tidak memerlukan waktu lama dan lebih praktis, tetapi jenis pereaksi yang dapat digunakan sangat banyak. Sehingga dibutuhkan pereaksi yang lebih selektif dan sensitif terhadap bahan pangan. Tujuan penelitian ini adalah untuk mengetahui selektifitas dan sensitifitas pereaksi pada bahan pangan. Selektivitas merupakan kemampuan yang hanya mengukur zat tertentu saja secara cermat dan seksama dengan adanya komponen lain yang mungkin ada dalam matriks sampel. Matriks merupakan cemaran, pengotor atau pengganggu, baik sengaja atau tidak sengaja berada dalam suatu komponen (Shita, 2016).

Penelitian pengujian formalin terhadap beberapa bahan pangan dengan beberapa macam pereaksi telah 
dilakukan pada penelitian sebelumnya dimana pereaksi Schiff, $\mathrm{CuSO}_{4}$, dan $\mathrm{FeCl}_{3}$ merupakan pereaksi yang relatif paling memuaskan untuk mendeteksi formalin dengan konsentrasi sampai 0,01 ppm (Syafitri et al., 2012). Perlu dilakukannya uji selektifitas dan sensitifitas pereaksi deteksi formalin yaitu $\mathrm{KMnO}_{4}$, Scryver, Fehling, Nash, dan Schiff pada beberapa sampel bahan pangan seperti tahu, daging ayam, ikan asin, dan mie basah. Sehingga bisa didapatkan informasi pereaksi mana yang lebih selektif dan sensitif dalam mendeteksi formalin pada bahan pangan. Berdasarkan latar belakang di atas maka penulis tertarik untuk mengetahui selektivitas dan sensitivitas dari beberapa pereaksi untuk analisis kualitatif formalin pada bahan pangan.

\section{Metode Penelitian}

Penelitian ini dilakukan secara analisis deskriptif kualitatif dengan menggunakan pereaksi formalin (Schiff, Scryver, $\mathrm{KMnO}_{4}$, Fehling, dan Nash) terhadap sampel bahan pangan yaitu daging ayam, tahu, ikan asin, dan mie basah yang telah diberi formalin dengan variasi konsentrasi 0,$01 ; 0,1 ; 1,0 ; 10$; 100; dan 1000 ppm untuk mengetahui sensitivitas dan selektivitas pereaksi tersebut.

\section{Alat dan Bahan}

Alat-alat yang dibutuhkan adalah timbangan analitik, pipet volume, pipet ukur, labu ukur, beaker glass, spatel, pipet tetes, tabung reaksi, dan gelas ukur. Bahan-bahan yang digunakan adalah daging ayam, tahu, ikan asin, mie basah, akuades, formalin 37\%, $\mathrm{KMnO}_{4}$ $1 \%$, fuchsin, natrium sulfit anhidrat, asam nitrat, $\mathrm{CuSO}_{4}, \mathrm{H}_{2} \mathrm{SO}_{4} \mathrm{P}, \mathrm{KNa}$-tartrat, natrium kromatopat, fenilhidrazin klorida, asam klorida, kalium ferrisianida (Kalium heksasianoferat(III) P), ammonium asetat, dan asam asetat. Jalannya Penelitian

1. Pembuatan larutan standar formalin Larutan standar formalin disiapkan dalam berbagai konsentrasi yang dibuat dari larutan induk formalin $37 \%$ yang kemudian diencerkan menjadi konsentrasi 1000; 100; 10; 1,0; 0,1; dan 0,01 ppm sebanyak $1000 \mathrm{ml}$.

2. Pembuatan pereaksi uji formalin a. Pereaksi Schiff

Sebanyak $200 \mathrm{mg}$ fuchsin P dilarutkan dalam $120 \mathrm{ml}$ air panas, dan dibiarkan dingin. Larutan ini ditambahkan larutan 2 gram 
natrium sulfit anhidrat $\mathrm{P}$ dalam 20 $\mathrm{ml}$ air, kemudian ditambahkan $2 \mathrm{ml}$ asam klorida P. Campuran diencerkan dengan air hingga 200 $\mathrm{ml}$, dibiarkan selama tidak kurang dari 1 jam (Depkes, 1979).

b. Pereaksi Nash.

Pereaksi Nash dibuat dengan melarutkan 150 gram ammonium asetat, $3 \mathrm{ml}$ asam asetat, $2 \mathrm{ml}$ asetil aseton dengan akuades sampai $1000 \mathrm{ml}$ (Rohman, 2007).

c. Pereaksi KMnO4 1\%

Kalium permanganat $P$ ditimbang sebanyak 1 gram dilarutkan dengan $100 \mathrm{ml}$ akuades sampai tanda batas (Depkes Rl, 1979).

\section{d. Pereaksi Fehling}

Fehling $\mathrm{A}: \mathrm{H}_{2} \mathrm{SO}_{4} \mathrm{P}$ dimasukkan secara perlahan ke dalam beaker glass berisi $100 \mathrm{ml}$ akuades sambil sesekali diaduk secara perlahan. Kemudian garam tembaga dimasukkan ke dalam larutan tersebut, setelah larut kemudian diencerkan dengan akuades hingga volume larutan menjadi $50 \mathrm{ml}$ dan pereaksi dipindahkan ke dalam botol reagen.

Fehling B: sebanyak $250 \mathrm{ml}$ akuades dimasukkan ke dalam beaker glass. $\mathrm{NaOH}$ sebanyak 8,33 g dilarutkan ke dalam akuades, dan 34,6 g garam tartrat ditambahkan dan diencerkan larutan ini sampai volume larutan menjadi $50 \mathrm{ml}$. Selanjutnya larutan Fehling A dan Fehling $B$ dicampur dengan perbandingan volume yang sama pada saat akan digunakan (Ham, 2008).

e. Pereaksi Schryver

Fenilhidrazina hidroklorida $1 \%$ dan kalium ferrisianida $1 \%$ ditimbang sebanyak berturut-turut 2,5 gram dan 25 gram. Bahan tersebut ditambahkan asam klorida pekat sebanyak $5 \mathrm{ml}$.

3. Penyiapan sampel bahan pangan berformalin dan tidak berformalin

a. Pembuatan bahan pangan tidak berformalin

Bahan pangan (daging ayam, tahu, ikan asin, dan mie basah) ditimbang masing-masing sebanyak 300 mg, kemudian digerus dan masing-masing dimasukkan ke dalam 6 tabung reaksi.

b. Pembuatan bahan pangan berformalin

Bahan pangan dipotong terlebih dahulu kemudian direndam ke dalam larutan formalin selama 2 jam dengan variasi konsentrasi 
$1000 ; 100 ; 10 ; 1,0 ; 0,1 ;$ dan 0,01

ppm. Kemudian bahan pangan masing-masing ditimbang sebanyak 300 gram lalu digerus dan dimasukkan masing-masing ke dalam 6 tabung reaksi.

4. Pengujian selektivitas dan sensitivitas pereaksi terhadap larutan standar formalin (kontrol positif)

Larutan standar formalin diencerkan menjadi 1000; 100; 10; 1,0; 0,1; dan 0,01 ppm ke dalam enam tabung yang berbeda, kemudian pada setiap tabung ditambahkan masing-masing pereaksi uji (Schiff, Scryver, $\mathrm{KMnO}_{4}$, Fehling, dan Nash). Pengujian dilakukan pada rentang konsentrasi formalin yang menunjukkan hasil positif dan negatif terhadap masing-masing pereaksi uji.

5. Pengujian sensitivitas dan selektivitas sampel bahan pangan tidak berformalin

Bahan pangan yang tidak berformalin ditambahkan pereaksi uji Schiff, Scryver, Nash, $\mathrm{KMnO}_{4}$, dan Fehling pada tiap-tiap tabung reaksi. Kemudian pada tabung reaksi tersebut diamati setiap perubahan warna yang terjadi pada tabung reaksi.

6. Pengujian sensitivitas dan selektivitas sampel bahan pangan berformalin
Bahan pangan yang telah direndam formalin dengan variasi konsentrasi $1000 ; 100 ; 10 ; 1,0 ; 0,1$; dan 0,01 ppm diambil masing-masing $300 \mathrm{~g}$ kemudian digerus dan dimasukkan ke dalam 6 tabung reaksi. Kemudian pada tabung reaksi tersebut dilakukan pengujian pereaksi untuk melihat selektivitas dan sensitivitas pereaksi uji terhadap sampel bahan pangan, diamati setiap perubahan warna yang terjadi pada masing-masing tabung reaksi.

\section{Hasil dan Pembahasan}

Pada penelitian analisis kualitatif formalin ini bertujuan untuk mengetahui selektifitas dan sensitifitas beberapa pereaksi formalin pada bahan pangan. Hasil yang didapatkan pada uji selektifitas menggunakan pereaksi Schiff pada keempat sampel (tahu, ayam potong, mie basah, dan ikan asin) menunjukkan hasil uji positif ditandai dengan terbentuknya warna ungu. Pereaksi Schiff dan formalin bereaksi menghasilkan warna ungu merupakan hasil reaksi kondensasi antara formalin (formaldehida) yang mengandung gugus karbonil $(\mathrm{C}=\mathrm{O})$ dengan larutan Schiff (Kusumawati dan Trisharyanti, 2004). 
Hasil uji selektifitas pereaksi $\mathrm{KMnO}_{4}$ pada keempat sampel menunjukkan hasil uji positif yang ditandai dengan perubahan warna ungu menjadi warna coklat. $\mathrm{KMnO}_{4}$ dan formalin dapat bereaksi menghasilkan warna coklat berdasarkan reaksi oksidasi dengan dihasilkannya $\mathrm{MnO}_{2}^{-}$(Sikanna, 2016).

Hasil uji selektifitas pereaksi Scryver pada keempat sampel menunjukkan hasil uji positif yang ditandai dengan terbentuknya larutan kompleks berwarna merah, yaitu senyawa kompleks formazil suatu senyawa yang memiliki gugus azo (mengandung nitrogen). Pereaksi Scryver merupakan pereaksi yang spesifik untuk uji formalin yang terdiri dari fenilhidrazina hidroklorida, kalium ferrisianida, dan $\mathrm{HCl}$ p. Reaksi kimia yang terjadi berdasarkan kondensasi antara formalin dengan fenilhidrazin, yang pada suatu reaksi oksidasi, akan menghasilkan suatu basa lemah (Suryadi et al., 2014).

Hasil uji selektifitas pereaksi
Nash pada keempat sampel
menunjukkan hasil uji positif yang
ditandai dengan terbentuknya warna
kuning terang. Semakin kuning warna
larutan yang didapat maka konsentrasi
formalin yang didapat dalam sampel juga
formalin yang didapat dalam sampel juga semakin besar. Formaldehida dengan penambahan pereaksi Nash disertai pemanasan selama 30 menit akan menghasilkan warna kuning mantap (Saptarini et al., 2011).

Hasil uji selektifitas pereaksi Fehling pada keempat sampel menunjukkan hasil uji negatif yang ditandai dengan tidak terbentuknya endapan $\mathrm{Cu}_{2} \mathrm{O}$ yang berwarna merah bata. Hal ini mungkin disebabkan karena pengaruh kestabilan pereaksi Fehling seperti harus dilakukannya pemanasan karena pereaksi Fehling kurang stabil pada larutan dingin (temperatur rendah) sehingga dibutuhkan pemanasan agar Fehling stabil. Perubahan warna terjadi karena senyawa aldehida dioksidasi menjadi asam karboksilat dan terbentuk endapan CuO berwarna merah bata (Fessenden, 1986).

Uji selektifitas adalah suatu cara untuk mengukur kemampuan suatu pereaksi yang hanya mengukur zat tertentu saja secara cermat dan seksama dengan adanya komponen lain yang mungkin ada dalam matriks sampel (Susanti, 2010). Dari hasil pengujian, pereaksi Schiff, KMnO4, Scryver, dan Nash, adalah pereaksi yang cukup selektif untuk mendeteksi formalin sedangkan pereaksi Fehling tidak selektif 
karena pada kontrol positif dan sampel bahan pangan pengujian tidak mampu mendeteksi formalin.

Uji sensitifitas adalah suatu cara untuk mengetahui batas konsentrasi formalin yang masih dapat terdeteksi oleh pereaksi uji. Pengujian sensitivitas pereaksi uji dilakukan terhadap larutan formalin konsentrasi 1000; 100; 10; 10; 0,1; dan 0,01 ppm, dan pada sampel bahan pangan yang telah direndam dengan larutan formalin. Pereaksi uji terhadap Schiff pada larutan standar formalin (kontrol positif) pada semua bahan pangan memiliki sensitifitas yang baik dan dapat mendeteksi formalin hingga 0,01 ppm pada tiga kali pengulangan. Pada pengujian bahan pangan ikan asin dan tahu, pereaksi Schiff pada tiap pengulangan dapat mendeteksi formalin hingga 0,01 ppm, sedangkan pada bahan pangan ayam dan mie basah pengulangan I dan || dapat mendeteksi formalin hingga 0,01 ppm sedangkan pada pengulangan ke III pereaksi schiff hanya mampu mendeteksi formalin pada konsentrasi 100 ppm. Pada pereaksi $\mathrm{KMnO}_{4}$ terhadap larutan standar formalin dan sampel bahan pangan ikan asin, tahu, ayam dan mie basah, pada tiap pengulangan dapat mendeteksi formalin hingga konsentrasi 0,01 ppm. Pada pereaksi Scryver dan Nash terhadap larutan standar dan sampel bahan pangan mie basah pada pengulangan I, II dapat mendeteksi formalin hingga konsentrasi $10 \mathrm{ppm}$ sedangkan pada sampel bahan pangan ikan asin, tahu, dan ayam pada tiap pengulangan hanya dapat mendeteksi formalin hingga konsentrasi 100 ppm. Pada pereaksi Fehling terhadap larutan standar dan sampel bahan pangan tidak mampu mendeteksi formalin karena tidak terbentuknya warna merah bata setelah dilakukannya pemanasan.

Pereaksi Schiff dan $\mathrm{KMnO}_{4}$ merupakan pereaksi yang paling sensitif dalam mendeteksi formalin pada bahan pangan tahu, ayam potong, mie basah, dan ikan asin sampai konsentrasi 0,01 ppm. Perbedaan sensitifitas tiap pereaksi pada bahan pangan bisa disebabkan oleh keempat bahan pangan yang memiliki komposisi gizi yang berbeda-beda seperti adanya karbohidrat, lemak, dan juga protein yang dapat mempengaruhi hasil reaksi seperti mengganggu terjadinya reaksi. Misalnya pada tahu, selain mengandung protein juga mengandung karbohidrat dimana pada rumus strukturnya protein dan karbohidrat juga mengandung gugus 
aldehida sama seperti pada formalin, sehingga pada analisis kualitatif formalin dapat bereaksi dengan pereaksi Schiff, $\mathrm{KMnO}_{4}$, Fehling, dan Nash (Shita, 2016).

\section{Simpulan}

Dari hasil penelitian analisis kualitatif terhadap formalin menunjukkan pereaksi yang selektif untuk identifikasi formalin adalah pereaksi Schiff, $\mathrm{KMnO}_{4}$, Scryver, dan Nash. Pereaksi yang sensitif terhadap formalin hingga 0,01 ppm adalah Schiff dan $\mathrm{KMnO}_{4}$. Sedangkan pereaksi Scryver dan Nash hanya mampu mendeteksi formalin hingga konsentrasi 100 ppm.

\section{Daftar Pustaka}

Antoni, S. 2010. Analisa kandungan formalin pada ikan asin dengan metode spektrofotometri di Kecamatan Tampan Pekanbaru. Skripsi. Fakultas Tarbiyah dan Keguruan, UIN Sultan Syarif Kasim Pekanbaru.

Fessenden, R.J. 1986. Kimia Organik. Yogyakarta: Penerbit Erlangga.

Jamlean, F.V. 2016. Identifikasi formalin pada berbagai jenis ikan asin yang beredar di Pasar Tradisional $\mathrm{X}$ di Kabupaten Y Yogyakarta periode Juni 2015. Jurnal Farmasi Akfarindo, 1(1):43-47.

Drastini, Y. dan Widiasih, D.A. 2009. Studi metode schiff untuk deteksi kadar formalin pada ikan bandeng laut (Chanos-chanos). Jurnal Sain Veteriner, 27(1):21-27.

Shita, A.E. 2016. Selektivitas metode analisis formalin secara spektrofotometri dengan pereaksi Schiff's. Skripsi. FMIPA, Universitas Negeri Yogyakarta.

Syafitri, W., Firmansyah, A. Hamdani, S. 2012. Skrining pereaksi spot test untuk deteksi kandungan formalin pada bahan pangan. Jurnal Sains dan Teknologi Farmasi Indonesia, 1(2):1-11.

Khaira, K. 2016. Pemeriksaan formalin pada tahu yang beredar di Pasar Batusangkar menggunakan kalium permanganat $\left(\mathrm{KMnO}_{4}\right)$ dan kulit buah naga. Sainstek Jurnal Sains dan Teknologi, 7(1):69-76.

Kusumawati, F. dan Trisharyanti, I.D.K. 2004. Penetapan kadar formalin yang digunakan sebagai pengawet dalam bakmi basah di pasar wilayah Kota Surakarta. Jurnal Penelitian Sains \& Teknologi, 5(1):131-140.

Departemen Kesehatan RI. 1979. Farmakope Indonesia. Edisi III. Jakarta: Depkes RI.

Rohman, A. 2007. Analisis Makanan. Yogyakarta: Gadjah Mada University Press.

Ham, M. 2008. Membuat Reagen Kimia di Laboratorium. Jakarta: Penerbit PT Bumi Aksara.

Sikanna, R. 2016. Analisis kualitatif kandungan formalin pada tahu 
yang dijual di beberapa Pasar di Kota Palu. Kovalen, 2(2):85-90.

Suryadi, H., Kurniadi, M., Melanie, Y. 2014. Analisis formalin dalam sampel ikan dan udang segar dari Pasar Muara Angke. Majalah IImu Kefarmasian, 7(3):16-31.

Susanti, S. 2010. Penetapan kadar formaldehid pada tahu yang dijual di Pasar Ciputat dengan metode spektrofotometri UV-Vis disertai kolorimetri menggunakan pereaksi Nash. Skripsi. FKIK, UIN Syarif Hidayatullah, Jakarta.

Saptarini, N.M., Wardati, Y., Supriatna, U. 2011. Deteksi formalin dalam tahu di Pasar Tradisional Purwakarta. Jurnal Penelitian Sains \& Teknologi, 12(1):37-44. 